\title{
Doxylamine Succinate
}

National Cancer Institute

\section{Source}

National Cancer Institute. Doxylamine Succinate. NCI Thesaurus. Code C47501.

A pyridine derivate histamine $\mathrm{H} 1$ antagonist with pronounced sedative properties.

Doxylamine succinate competitively blocks the histamine $\mathrm{H} 1$ receptor and limits the typical allergic and anaphylactic responses, including bronchoconstriction, vasodilation, increased capillary permeability, and spasmodic contraction of gastrointestinal smooth muscle, caused by actions of histamine on bronchial and gastrointestinal smooth muscles, and on capillaries. This drug also prevents histamine-induced pain and itching of the skin and mucous membranes. 